\title{
Determination of Snowmelt Water Quality in Outdoor Green Areas: A Case Study at Van Province (Turkey)
}

\author{
Okan Yeler ${ }^{1}$, Menekşe Taş Divrik ${ }^{2}$ (D), Belgin Çamur Elipek ${ }^{3}$ (D)
}

Cite this article as: Yeler, O. Tas Divrik, M., \& Camur Elipek, B. (2021). Determination of Snowmelt Water Quality in Outdoor Green Areas: A Case Study at Van Province (Turkey). Aquatic Sciences and Engineering, 36(2), 78-84

ORCID IDs of the author: O.Y. 0000-0002-0405-4829; M.T.D. 0000-0002-4828-2575; B.Ç.E. 0000-0002-0954-8967

'Van Yüzüncü Yıl University, Muradiye Vocational School, Van, Turkey

${ }^{2}$ Sivas Cumhuriyet University, Şarkışla Așık Veysel Vocational School,

Sivas, Turkey

${ }^{3}$ Trakya University, Faculty of Science, Department of Biology, Edirne, Turkey

Submitted:

04.09.2020

Revision Requested:

12.10.2020

Last Revision Received:

17.10.2020

Accepted:

18.10.2020

Online Published:

28.01.2021

Correspondence:

Okan Yeler

E-mail:

okanyeler@yyu.edu.tr

(C) Copyright 2021 The Author(s)

Available online at

https://dergipark.org.tr/ase

\begin{abstract}
Freshwater resources are used for many purposes such as drinking, tap water, industrial usage and agricultural irrigation. Although unpolluted surface waters and groundwater are preferred for the irrigation of landscape plants in parks and gardens, snowmelt water is generally ignored. Like other precipitation types, snow can absorb solid and liquid substances in the atmosphere and it can rain on the earth with its natural chemical structure changed. Also, this water from snowmelt which includes different chemicals can enter surface waters and groundwater resources. In this study, the snowmelt water quality in outdoor green areas of the Van Province was examined. Some physico-chemical features ( $\mathrm{pH}$, conductivity, salinity, $\mathrm{Ca}, \mathrm{Mg}$, total hardness, $\mathrm{Cl}, \mathrm{NO}_{3}-\mathrm{N}, \mathrm{NO}_{2}-\mathrm{N}, \mathrm{SO}_{4}$, and $\mathrm{PO}_{4}$ ) of the snow samples were taken at monthly intervals from six sampling stations between the dates of December 2019 - February 2020. Also, metal ion concentrations (Cd, Pb, As, Cu, Cr, Co, $\mathrm{Ni}$, Zn, Fe, Mn, B, Se, Ba, Al, Na, Be, V, Mo, Si, K, Sr, Ag, Sb, Tl) and the values of SAR (Sodium Adsorption Ratio) and $\mathrm{Na} \%$ in some sampling stations, which have intense industrial and settlements located in the area, were determined to evaluate the water quality level of the snowmelt water. While, it was observed that some parameters values exceeded the first quality level when compared with the quality levels of the surface water resources control regulation of Turkey and the rates in irrigation water quality values, a general evaluation of the results showed that snowmelt can be alternative irrigation water for plants. Also, the species of the landscape plants in the studied area were identified and the possible effects of the parameters on the development of the plants were discussed.
\end{abstract}

Keywords: Freshwater, snowmelt, landscape plants, metal ions, irrigation water

\section{INTRODUCTION}

In urban outdoor green areas, the visual landscape is provided by annual or seasonal plants. The surface waters and groundwater are generally used as irrigation resources for the plants in outdoor green areas. Furthermore, snow meltwater released by snowfall is also a potential irrigation water source for plants in these areas at spring season especially (Cooper, Dullinger, \& Semenchuk, 2011). But, snow properties which are ignored generally can cause significant changes in soil and vegetation processes (Rixen et al., 2008). The atmosphere, one of the main receptive environments such as water and soil, may also be exposed to increasing pollutants, especially due to the intensive use of fossil fuels in winter. As the water vapour in the atmosphere condenses and descends to the soil in the form of rain, snow or hail, it is likely that these pollutants involved in precipitation have some effect on the soil and therefore on the plants (Rixen et al., 2008; Seven, Can, Darende, \& Ocak, 2018). However, depending on the use of fossil fuels and industrial activities, pollutants enter the atmosphere and can be included in the precipitation. Thus it can lead to negative 
physico-chemical contents that affect plant growth (Yücedağ \& Kaya, 2016). In some studies, it has been reported that snowmelt water contains some elements in higher proportions than rainwater, and surface water is affected by the melting of snow (Hagen \& Langeland, 1973; Johannessen \& Henriksen, 1978; Jeffries, 1990; Pehlivan, 2016; Galeczka, Sigurdsson, Eiriksdottir, Oelkers, \& Gislason, 2016).

Up to now, there has not been a study on the snowmelt water quality in the landscape areas of the Van Province. In this study, physico-chemical properties of water from snowmelt in the outdoor green areas of Van province were examined. Thus, it was aimed to determine snowmelt water quality which can enter the surface and groundwater resources. Also, the possible effects of snow meltwater as an alternative irrigation water on the growth of the landscape plants were discussed in this study.

\section{MATERIALS AND METHODS}

The Van province which is located on east side of Turkey and has $20921 \mathrm{~km}^{2}$, is a major city with a population of over 1 million. Fossil fuels for heating and transportation are used throughout the city, and organisations from different industries are also located in the region. There are many parks and gardens created for recreation in the outdoor green areas of the city and they have many different landscape plants which are completely under snow in the winter season.

In this study, a total of 6 sampling stations were selected from recreational outdoor green areas which contain plants planted by the municipality: Van-Kocaeli Dostluk Park (st1), Kurtuluş Park (st2), 15 Temmuz Şehitler Park (st3), Atatürk Kültür Park (st4), Yüzüncü Yil University Alle Park (st5), Iskele Yasar Kemal Park (st6) (Fig.1). The snow samples were taken from the surface to $5 \mathrm{~cm}$ of snow package at monthly intervals (December 2019, January 2020 and February 2020) under sterile conditions, they put into 1 $\mathrm{L}$ polyethylene cups and allowed to melt at room temperature $\left(+24^{\circ} \mathrm{C}\right)$. The values of $\mathrm{pH}$ and conductivity $\left(\mathrm{EC}\right.$ as $\left.\mu \mathrm{S} \mathrm{cm} \mathrm{cm}^{-1}\right)$ were measured during the field studies and the water samples from snowmelt were filtered by filtered paper and were transported to the laboratory to analyse $\mathrm{Ca}, \mathrm{Mg}$, total hardness (TH), Cl, salinity, $\mathrm{NO}_{3}-\mathrm{N}, \mathrm{NO}_{2}-\mathrm{N}, \mathrm{SO}_{4}, \mathrm{PO}_{4}$ (Egemen \& Sunlu, 1999).

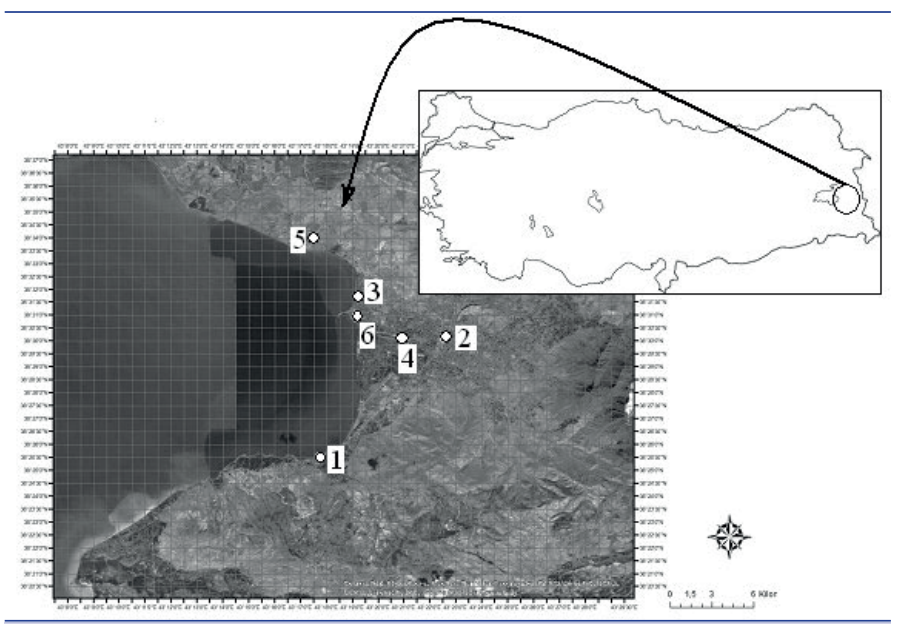

Figure 1. Location of Van province and the sampling stations.
Also, the melting snow samples taken from the sampling stations st1, st2 and st5, which are located at areas that have intense industrial and settlements, were put into sterile polyethylene bottles

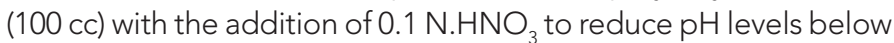
2 and transported to the laboratory to measure some metal ion concentrations (Van Loon, 1980; Welz \& Sperling, 1999). The average values were taken after three replicated at flame atomic absorption spectrophotometer (Perkin-Elmer A-Analyst 800 device). Also, the values of $\mathrm{Na}^{+}, \mathrm{Ca}^{+2}, \mathrm{Mg}^{+2}, \mathrm{~K}^{+}$ions were converted to me $\mathrm{L}^{-1}$ from the obtained chemical analysis results and the SAR value (sodium adsorption ratio) and the $\mathrm{Na} \%$ (sodium percentage ratio) were calculated (Ayers \& Wescott, 1985; FAO, 2007).

Alp (1999), Yeler \& Yeler (2019) and Van Lake Basin Virtual Herbarium (Demirkuş, 2019) were used to identify the landscaping plants. The species were separated into four groups as evergreen trees $(E T)$, deciduous trees (DT), evergreen shrubs (ES), and deciduous shrubs (DS). The Bray-Curtis Cluster Analysis in the program "BioDiversity Pro 2.0" was used to determine the similarities of the sampling stations for their floral diversity (McAleece, Gage, Lambshead, \& Paterson, 1997).

\section{RESULTS AND DISCUSSION}

Snow thicknesses at the sampling stations were measured as 7 $\mathrm{cm}$ (Dec.), $15 \mathrm{~cm}$ (Jan.), and $7 \mathrm{~cm}$ (Feb.) The physico-chemical results and their average values of the snowmelt water samples are presented in Table 1 and Figure 2.

Physico-chemical properties: The $\mathrm{pH}$ can affect the availability of macro and micro nutrients by plants when it has an undesirable level (Toor \& Lusk, 2011). $\mathrm{pH}$ values were observed between the levels of 6.5 and 8.4 in this study (Toor \& Lusk, 2011). When the results were evaluated according to the limits in Surface Water Resources Control Regulation (SWRCR) of Turkey and irrigation water quality (Ayers \& Westcot, 1985; Toor, 2009; Anonymous, 2004, 2010; Toor \& Lusk, 2011; Erdoğan \& Dağdelen, 2012): the EC were found at compatible levels for the freshwater character $\left(45.7-131.5 \mu \mathrm{S} \mathrm{cm}^{-1}\right)$. These values showed parallelism with the salinity (0.02-0.05\%), the chloride (1.99-14.99 $\left.\mathrm{mg} \mathrm{L}^{-1}\right)$ and the $\mathrm{TH}$ values (2.4-5.4 FS $)$. The EC values should range between $0-3 \mathrm{dS}$ $\mathrm{m}^{-1}$ for irrigation water and they should have a value of $<700 \mu \mathrm{S}$ $\mathrm{cm}^{-1}$ as there is human contact in landscape areas such as parks and gardens (Ayers \& Westcot, 1985; Anonymous, 2010). In this study, the EC values were determined at T1 class in terms of irrigation water, and high quality in terms of classification by the Schofield method (Erdoğan \& Dağdelen, 2012). In a study carried out at Van Çaldıran Plain, which is located close to our area of study, it was reported that the EC in the surface waters of the region was $1203 \mu \mathrm{S} \mathrm{cm} \mathrm{cm}^{-1}$ higher than our results (Aydın, 2017). Woodless plants rather than annual plants are sensitive to chloride concentrations (Ayers \& Westcot, 1985). The $\mathrm{Cl}$ values were observed at first class water quality in this study, and $<4$ me $\mathrm{Cl} \mathrm{L}^{-1}$ signals that this water resource could be used even in the irrigation of sensitive plants according to the Schofield method (Anonymous, 2004; Erdoğan \& Dağdelen, 2012). It is reported that irrigation of the soil with this water has high a sodium concentration and disturbs the physical structure of the soil and this prevents plant growth, indirectly (Erdoğan \& Dağdelen, 2012). Although 
Table 1. The results of physico-chemical features of the sampling stations.

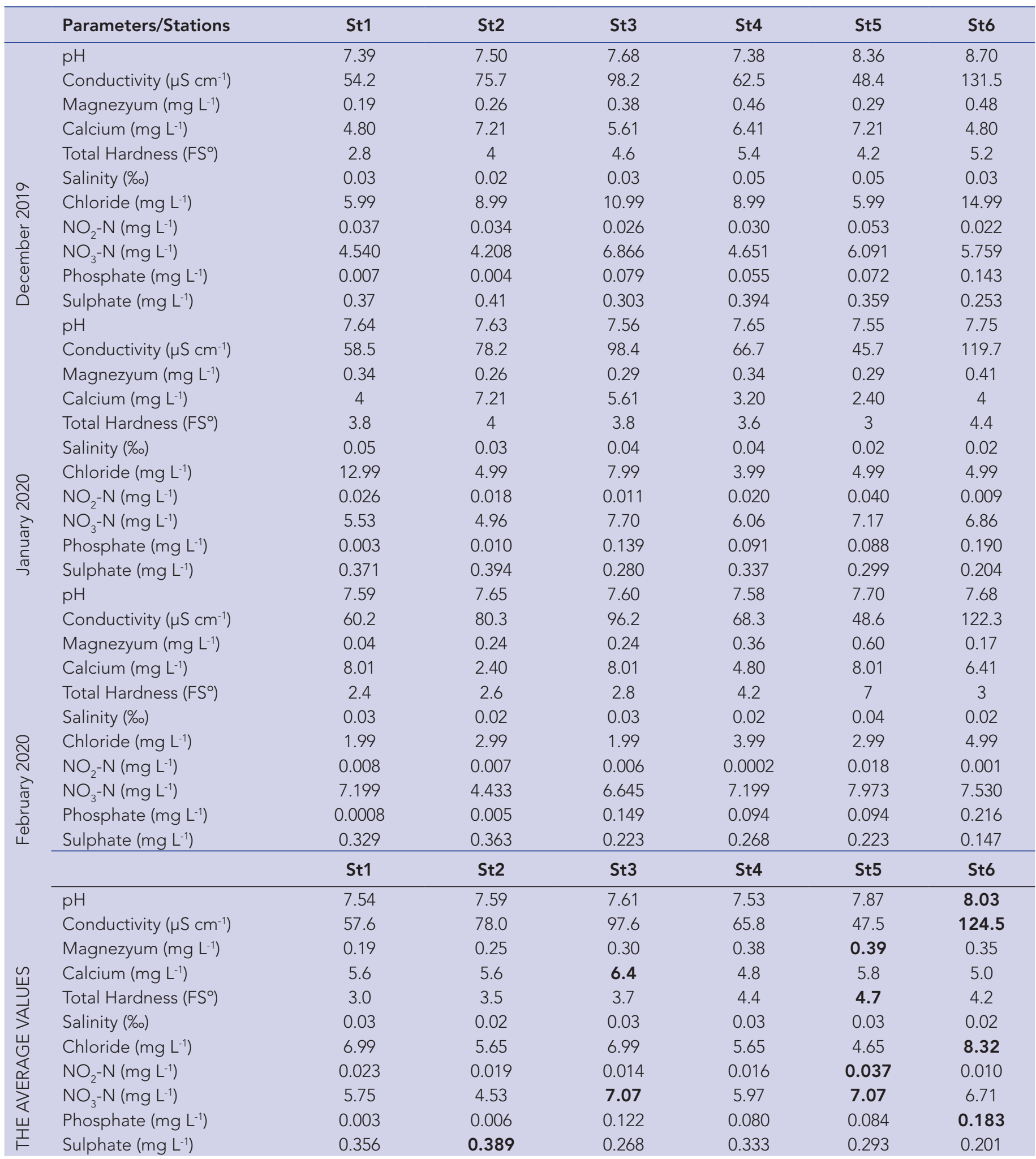

most annual plants are not very sensitive to sodium, the excess sodium rate still has a toxic effect on plants. In addition, it is recommended to determine the SAR (Sodium Adsorption Ratio) value for the effect of sodium in irrigation waters (Ayers \&
Wescott, 1985). In this study, the SAR and Na\% did not exceed the limits for irrigation water quality (SAR values and $\mathrm{Na} \%$ were calculated as 0.11 and $12.5 \%$ for st $1,0.12$ and $11.9 \%$ for st2, 0.40 and $8.4 \%$ for st5, 0.07 and $7 \%$ for December, 0.14 and $16 \%$ for 


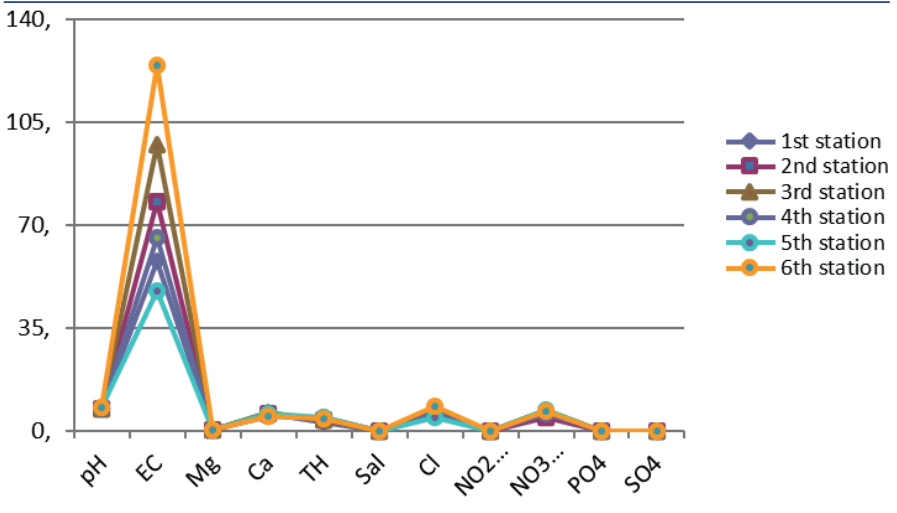

Figure 2. The distribution of average values of the physicochemical parameters in the sampling stations.

January, 0.07 and $8 \%$ for February. So, the SAR values were found $<1$ value and were determined in the A1 category (Erdoğan \& Dağdelen, 2012). The Na\% values were found far below the 50$60 \%$ value that would damage the trees and decorative woody plants that are more sensitive to soil and especially sodium (Ayers \& Westcot, 1985; Erdoğan \& Dağdelen, 2012). All the sampling stations were found to be of first class quality and had desirable values in terms of $\mathrm{SO}_{4}$, while the $\mathrm{NO}_{3}-\mathrm{N}$ values exceed this level (Ayers \& Westcot, 1985; Anonymous, 2004). Also, the $\mathrm{NO}_{2}-\mathrm{N}$ ratios were found to be of second and third class quality while the $\mathrm{PO}_{4}$ contents were found at first class in all of the sampling stations except st 5 which has the most landscape plant diversity. However, it may be more appropriate to determine the amount of nitrogen to evaluate the toxic effects of the nitrogen content contained in these compounds on plants. According to the calculations made based on the $\mathrm{NO}_{3}-\mathrm{N}$ values per $\mathrm{L}$ (the maximum value was measured as $7.9 \mathrm{mg} \mathrm{NO}_{3}-\mathrm{N} \mathrm{L}^{-1}$ in this study), it was observed that the nitrogen amount in the snow meltwaters was even below $5 \mathrm{mg} \mathrm{L}^{-1}$ which is a harmful ratio for sensitive plants in irrigation waters (Ayers \& Westcot, 1985; Erdoğan \& Dağdelen, 2012). In one study, it was reported that the $\mathrm{SO}_{4}$ concentrations increased from 2 to $14 \mathrm{mg} \mathrm{L}^{-1}$ in the stream waters in the area during and immediately after the snow melts (Siegel, 1981). In another study, it was determined that the $\mathrm{NO}_{3}-\mathrm{N}$ and $\mathrm{SO}_{4}$ in rainwater were higher than those in snow melt (Pehlivan, 2016). The $\mathrm{SO}_{4}$, which is less toxic than chlorine in irrigation waters, causes calcium to precipitate in high concentrations, causing plants not to get calcium (Arslan, Güler, Cemek, \& Demir, 2007). For this reason, it is recommended that the $\mathrm{SO}_{4}$ value in irrigation waters should not exceed $20 \mathrm{me} \mathrm{L}^{-1}$ (Ayers \& Westcot, 1985).

Metal ions: Data on the metal ions from the st1, st2, and st5 are presented in Table 2. In this study, the snowmelt water was determined as being of a first class water quality level in terms of the $\mathrm{Cd}, \mathrm{As}, \mathrm{Cu}, \mathrm{Cr}, \mathrm{Co}, \mathrm{Fe}, \mathrm{Mn}, \mathrm{B}, \mathrm{Se}, \mathrm{Ba}, \mathrm{Al}, \mathrm{Na}, \mathrm{Pb}, \mathrm{Zn}$ concentrations according to the SWRCR and the values of $\mathrm{Be}, \mathrm{Cd}, \mathrm{Ni}, \mathrm{V}, \mathrm{K}$, $\mathrm{Si}$ did not exceed the limit values given for irrigation water (Anonymous, 2004; Erdoğan \& Dağdelen, 2012; Smith, Oster, \& Sposito, 2014; Horuz, 2016). The chloride and boron are most commonly ions to lead toxic hazard to the plants at higher than the critical levels which is 70 ppm for $\mathrm{Cl}$ and 0.7 ppm for Boron (Toor
\& Lusk, 2011). In this study, the boron values determined between $0.001 \mathrm{mg} \mathrm{L}^{-1}$ and $0.4 \mathrm{mg} \mathrm{L}^{-1}$ were found to be of a quality that can be used even for sensitive plants, and they were found in first class level irrigation water quality according to the Christiansen system (Erdoğan \& Dağdelen, 2012). Although the values of $\mathrm{Pb}$ in st5 at January and $\mathrm{Zn}$ in st2 in December exceeded the first quality class levels at the SWRCR, these values were found at far below the toxic limits ( $5 \mathrm{mg} \mathrm{Pb} \mathrm{L}^{-1}$ and $2 \mathrm{mg} \mathrm{Zn} \mathrm{L}^{-1}$ ) for the irrigation of plants (Anonymous, 2010; Erdoğan \& Dağdelen, 2012). But, it was observed that the Mo value exceeded the limit value $0.01 \mathrm{mg} \mathrm{L}^{-1}(10 \mathrm{ppb})$ in January at the all sampling stations (Erdoğan \& Dağdelen, 2012). It is reported that the high rates of molybdenum, which are effective on nitrogen fixation in soil, will decrease the nitrogen fixation of the plant (Vuralın \& Müftüoğlu, 2012). When determining the quality of irrigation water for plants, the total salt concentration, the percentage of sodium and its relation to other cations, the amount of calcium and magnesium, as well as the Boron concentration, which has a significant impact on plants, are taken into consideration (Özer \& Köklü, 2019). Also, the chloride values were found at $<10 \mathrm{ppm}$. In one study it was reported that snow water is richer in terms of certain elements ( $\mathrm{Al}, \mathrm{Ba}, \mathrm{Cu}, \mathrm{Pb}, \mathrm{Mn}, \mathrm{Ni}, \mathrm{Si}, \mathrm{U}$ and $\mathrm{Zn}$ ) than rainwater (Pehlivan, 2016). The reason for this can be considered as the release of major ions, trace metals and organic pollutants contained in snow masses into surface waters with melting of snow (Jeffries, 1990). This provides a reduction in $\mathrm{pH}$, acid neutralisation capacity and base cations in surface waters, especially in spring (Jeffries, 1990).

While the ground of all the sampling stations was covered with mixed turfgrass, a total of 45 landscape plant species were determined in the study area and the species were separated to four groups: evergreen trees (ET) with 13 species, deciduous trees (DT) with 17 species, evergreen shrubs (ES) with 7 species, deciduous shrubs (DS) with 8 species (Table 3). The diversity of the landscape plant species in the sampling stations was determined as st5 $>$ st $1>$ st $4>$ st3 and st6 $>$ st2 (Figure 3 ). When the sampling stations were compared using the Bray-Curtis Cluster Analysis method in terms of the flora diversity they contain, it was found that the stations st 5 and st 1 were the most similar $(58 \%$ similarity), and the stations st 3 and st 2 were completely different from each other (Figure 4).

\section{CONCLUSION}

When the results of the snowmelt water obtained in this study was compared with the quality levels in SWRCR of Turkey (Anonymous, 2004), it was found that it has a first class water quality level for a lot of parameters. Although the concentrations of some parameters $\left(\mathrm{NO}_{2}-\mathrm{N}, \mathrm{NO}_{3}-\mathrm{N}, \mathrm{PO}_{4}, \mathrm{~Pb}\right.$ and $\left.\mathrm{Zn}\right)$ in some sampling stations exceeded the first quality level, these concentrations were not found above the limit values for irrigation (Ayers \& Westcot, 1985; Anonymous, 2004; Erdoğan \& Dağdelen, 2012). It was observed that only the Mo values exceed the maximum limit for irrigation water in all of the sampling stations in January. It is known that this metal is used in the steel industry and it is an essential element for higher plants and its toxicity danger in plants is small (Anke \& Seifert, 2007). The values of $\mathrm{pH}$, conductivity, $\mathrm{Na}, \mathrm{K}, \mathrm{Ca}, \mathrm{Mg}$, total alkalinity, $\mathrm{Cl}$, 
Table 2. The metal ion concentrations of the sampling stations.

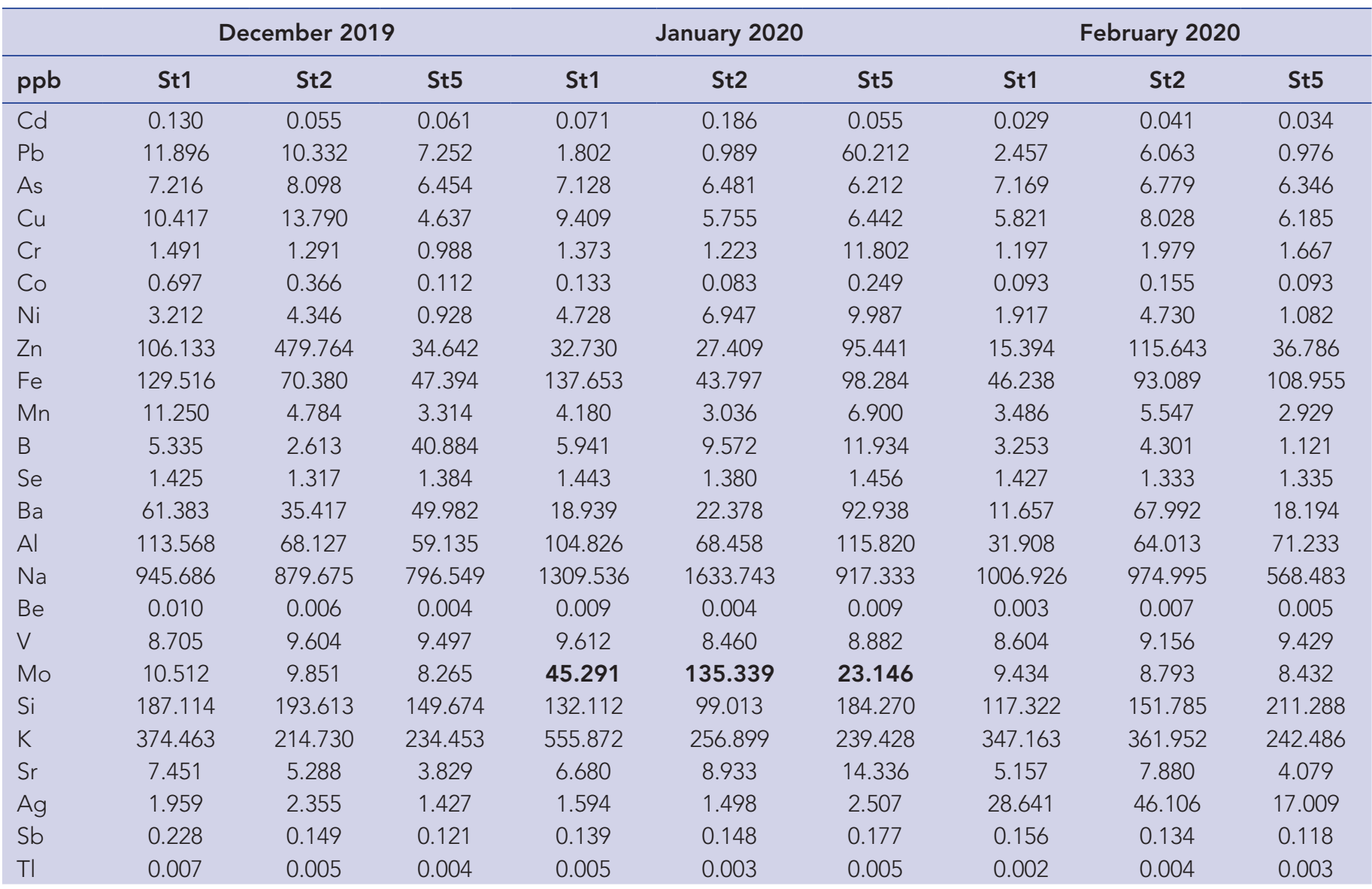

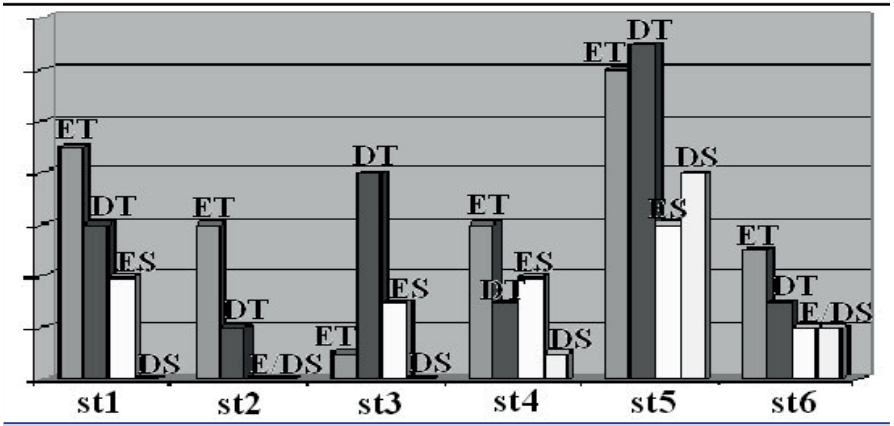

Figure 3. The distribution of landscape plants in the sampling stations.

$\mathrm{SO}_{4}$, total hardness, $\mathrm{B}$ and SAR are taken into consideration in determining the irrigation water quality (Ayers \& Westcot, 1985; Anonymous, 2004; FAO, 2007; Hussain, Alquwaizany, \& AlZarah, 2010; Erdoğan \& Dağdelen, 2012). When the data obtained in this study were evaluated considering the mentioned parameters, it was determined to have a very good water quality in terms of Schofield classification system (Erdoğan \& Dağdelen, 2012). Furthermore, according to the sodium diagram by Wilcox, the quality of the studied samples was found to be of $\mathbf{S 1}$ category (Hussain et al., 2010).

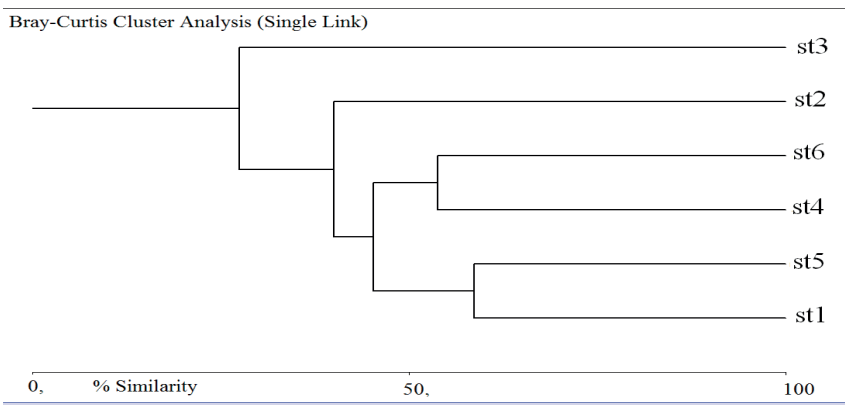

Figure 4. The similarities of the sampling stations according to the floral contents.

It has been observed that perennial woody plants are generally used as landscape plants in the study area. There is also mixed grass material in the study area and seasonal/sensitive cultivars are planted in these areas after the winter period. In this study, it was observed that some parameters exceeded the first class water quality level in the SWRCR (Anonymous, 2004). It is possible that these substances enter underground and surface water sources with the melting of snow and are to be used in the irrigation of sensitive plants to be planted in landscape areas after the winter period. 
Table 3. The list of landscape plant species determining in the sampling stations.

\begin{tabular}{|c|c|c|c|c|c|c|c|}
\hline Group & Species $\downarrow$ Stations $\rightarrow$ & 离 & $\stackrel{N}{\leftrightarrow}$ & $\underset{m}{m}$ & 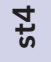 & $\stackrel{n}{\omega}$ & $\stackrel{0}{*}$ \\
\hline \multirow{13}{*}{ 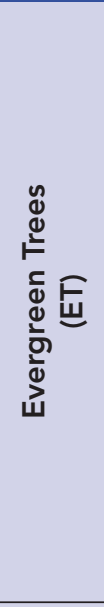 } & Abies nordmanniana & & $\bullet$ & & $\bullet$ & $\bullet$ & \\
\hline & $\begin{array}{l}\text { Aesculus hippocasta- } \\
\text { num }\end{array}$ & $\bullet$ & & & & $\bullet$ & \\
\hline & Cedrus libani & - & & & - & $\bullet$ & \\
\hline & Cupressus arizonica & $\bullet$ & $\bullet$ & & & $\bullet$ & \\
\hline & Platanus orientalis & & & & $\bullet$ & $\bullet$ & $\bullet$ \\
\hline & Populus alba & $\bullet$ & $\bullet$ & & & $\bullet$ & $\bullet$ \\
\hline & Picea pungens & $\bullet$ & & & & $\bullet$ & \\
\hline & Picea orientalis & - & $\bullet$ & & - & & $\bullet$ \\
\hline & Pinus nigra & $\bullet$ & $\bullet$ & & $\bullet$ & $\bullet$ & $\bullet$ \\
\hline & Pinus sylvestris & & & & - & - & \\
\hline & Quercus robur & $\bullet$ & $\bullet$ & & & $\bullet$ & \\
\hline & Thuja occidentalis & & & & & $\bullet$ & $\bullet$ \\
\hline & Thuja orientalis & - & & - & & - & \\
\hline \multirow{17}{*}{ 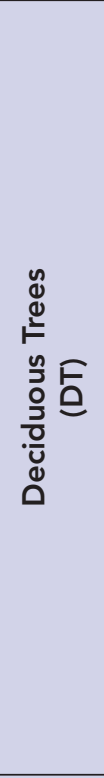 } & Acer negundo & & $\bullet$ & & & $\bullet$ & $\bullet$ \\
\hline & Acer platanoides & 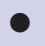 & & & & $\bullet$ & \\
\hline & Acer pseudoplatanus & $\bullet$ & & & & $\bullet$ & \\
\hline & Betula pendula & & & & & $\bullet$ & $\bullet$ \\
\hline & Catalpa speciosa & - & & & & $\bullet$ & \\
\hline & $\begin{array}{l}\text { Elaeagnus angusti- } \\
\text { folia }\end{array}$ & & & & - & • & \\
\hline & Fraxinus excelsior & & & $\bullet$ & $\bullet$ & $\bullet$ & \\
\hline & Malus domestica & & & & & $\bullet$ & \\
\hline & Malus floribunda & & & $\bullet$ & & $\bullet$ & \\
\hline & Morus alba & - & & $\bullet$ & & $\bullet$ & \\
\hline & Morus platanifolia & $\bullet$ & & & & $\bullet$ & \\
\hline & Prunus cerasifera & & & $\bullet$ & & $\bullet$ & \\
\hline & Salix alba & & $\bullet$ & & & - & \\
\hline & Salix babylonica & & & $\bullet$ & $\bullet$ & & • \\
\hline & Syringa vulgaris & & & $\bullet$ & & & \\
\hline & Tamarix tetrandra & $\bullet$ & & $\bullet$ & & & \\
\hline & Tilia tomentosa & & & $\bullet$ & & & \\
\hline \multirow{7}{*}{ 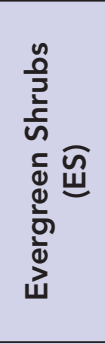 } & Ilex crenata & & & - & & & \\
\hline & $\begin{array}{l}\text { Juniperus horizon- } \\
\text { talis }\end{array}$ & $\bullet$ & & & $\bullet$ & $\bullet$ & • \\
\hline & Juniperus sabina & & & - & - & $\bullet$ & \\
\hline & Photinia Serrulata & $\bullet$ & & $\bullet$ & & $\bullet$ & \\
\hline & Prunus laurocerasus & - & & & & $\bullet$ & \\
\hline & Pyracantha coccinea & $\bullet$ & & & $\bullet$ & $\bullet$ & $\bullet$ \\
\hline & Viburnum tinus & & & & - & - & \\
\hline \multirow{8}{*}{ 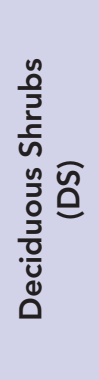 } & Berberis thunbergii & & & & & $\bullet$ & \\
\hline & $\begin{array}{l}\text { Cotoneaster horizon- } \\
\text { talis }\end{array}$ & & & & & $\bullet$ & \\
\hline & Cydonia japonica & & & & & - & \\
\hline & Ribes aureum & & & & & $\bullet$ & \\
\hline & Rosa polyantha & & & & $\bullet$ & $\bullet$ & - \\
\hline & Spiraea vanhouttei & & & & & $\bullet$ & \\
\hline & Viburnum opulus & & & & & $\bullet$ & $\bullet$ \\
\hline & Vitex agnus-castus & & & & & $\bullet$ & \\
\hline
\end{tabular}

Consequently, the quality of snow meltwater was examined in the outdoor green areas of the Van province in this study. The obtained results showed that the snow meltwater were not at the concentrations that would cause negative effects on the landscape plants in the study area. It was thought that the high values encountered at some stations from time to time may be due to the atmosphere. It is recommended that snow water is also considered as an alternative irrigation source for outdoor green areas and should be monitored periodically.

Ethics committee approval: Ethics committee approval is not required.

Conflict of interests: The authors declare that they have no conflict of interest.

\section{REFERENCES}

Alp, Ş. (1999). Van kenti yeşil dokusuna yönelik bazı ağaç ve çalıların saptanması üzerine bir araştırma. Van Yüzüncü Yıl University PhD Thesis.

Anke, M. \& Seifert, M. (2007). The biological and toxicological importance of molybdenum in the environment and in the nutrition of plants, animals and man. Acta Biologica Hungarica, 58(3), 311-324. [CrossRef] Anonymous (2004). Su Kirliliği Kontrol Yönetmeliği, Official Gazette No: 25687 of 31 December, Ankara. Retrieved from http://www.mevzuat .gov.tr (accessed 10.03.2020).

Anonymous (2010). Atıksu Arıtma Tesisleri Teknik Usuller Tebliği. TC. Çevre ve Orman Bakanlığı. Retrieved from http://www.resmigazete. gov.tr/eskiler/2010/03/20100320-7.Htm. (accessed 10.03.2020).

Arslan, H., Güler, M., Cemek, B. \& Demir, Y. (2007). Bafra Ovası yeraltı suyu kalitesinin sulama açısından değerlendirilmesi. Tekirdağ Ziraat Fakültesi Dergisi, 4(2), 219-226.

Aydın, F. (2017). Van Çaldıran ovası yüzey sularının içme ve sulama suyu açısından incelenmesi. Journal of the Institute of Science and Technology, 7(3), 171-179. [CrossRef]

Ayers, R. S. \& Westcot, D. W. (1985). Water quality for agriculture. FAO Irrigation and Drainage Paper, Rome. ISBN 92-5-102263-1

Cooper, E. J., Dullinger, S., \& Semenchuk, P. (2011). Late snowmelt delays plant development and results in lower reproductive success in the High Arctic. Plant Science, 180, 157-167. [CrossRef]

Demirkuş, N. (2019). The virtual herbarium of Lake Van Basin. Retrieved from http://Vanherbaryum.Yyu.Edu.Tr/Ingindex.Htm (accessed 10.01.2020)

Erdoğan, N. \& Dağdelen, E. (2012). Sulama Suyu Kalitesi. Retrieved from File:///C:/Documents\%20and\%20Settings/XP/Belgelerim/ Downloads/Sulamasuyukalitesi-Son\%20(1).pdf. (accessed 10.03.2020).

FAO (2007). Handbook On Pressurized irrigation Techniques, Chapter 7: Water Quality For Irrigation, FAO, Rome, ISBN 978-92-5-105817-6

Galeczka, I., Sigurdsson, G., Eiriksdottir, E. S., Oelkers, E. H. \& Gislason, S. R. (2016). The chemical composition of rivers and snow affected by the 2014/2015 Bárðarbunga Eruption, Iceland. Journal of Volcanology and Geothermal Research, 316, 101-119. [CrossRef]

Hagen, A. \& Langeland, A. (1973). Polluted snow in Southern Norway and the effect of the meltwater on freshwater and aquatic organisms. Environmental Pollution, 5, 45-57. [CrossRef]

Horuz, A. (2016). Silisyumun bitki gelişimine olan etkileri. Toprak Bilimi ve Bitki Besleme Dergisi, 6(2), 151-163.

Hussain, G., Alquwaizany, A. \& Al-Zarah, A. (2010). Guidlines for irrigation water quality and water management in the Kingdom of Saudi Arabia: An Overview. Journal of Applied Sciences, 10(2), 79-96. [CrossRef] 
Jeffries, D. S. (1990). Snowpack storage of pollutants, release during melting, and impact on receiving waters. Acidic Precipitation, 4, 107-132. [CrossRef]

Johannessen, M. \& Henriksen, A. (1978). Chemistry of snow meltwater: changes in concentration during melting. Water Resources Research, 14(4), 615-619. [CrossRef]

McAleece, N., Gage, J. D. G., Lambshead, P. J. D. \& Paterson, G. L. J. (1997). Biodiversity Professional Statistic Analysis Software. Jointly Developed By The Scottish Association For Marine Science And The Natural History Museum London. Retrieved from https://www.sams. ac.uk/science/outputs/ (accessed 10.03.2020).

Özer, Ç. \& Köklü, R. (2019). Aşağı Sakarya Nehri su kalitesinin sulama suyu açısından değerlendirilmesi. Çoruh Üniversitesi Doğal Afetler Uygulama ve Araştırma Dergisi, 5(2), 237-246. [CrossRef]

Pehlivan, R. (2016). Sarma Deresi Havzasındaki yağışın ayrışma ve su kalitesine etkisi, Düzce, Türkiye. Jeoloji Mühendisliği Dergisi, 40(1), 103-121. [CrossRef]

Rixen, C., Freppaz, M., Stoeckli, V., Huovinen, C., Huovinen, K. \& Wipf, S. (2008). Altered snow density and chemistry change soil nitrogen mineralization and plant growth. Arctic, Antarctic and Alpine Research, 40(3), 568-575. [CrossRef]

Seven, T., Can, B., Darende, B. N. \& Ocak, S. (2018). Hava ve toprakta ağır metal kirliliği. Ulusal Çevre Bilimleri Araştırma Dergisi, 1(2), 91-103.

Siegel, D. I. (1981). The effect of snowmelt on the water quality of Filson Creek and Omaday Lake, Northeastern Minnesota. Water Resources Research, Retrieved from https://doi.org/10.1029/WR017i001p00238. (accessed 10.03.2020). [CrossRef]
Smith, C. J., Oster, J. D. \& Sposito, G. (2014). Potassium and Magnesium in irrigation water quality assessment. Agricultural Water Management, Retrieved from http://dx.doi.org/10.1016/J. Agwat.2014.09.003. (accessed 10.03.2020). [CrossRef]

Toor, G. S. (2009). Book review: Turfgrass and landscape irrigation water quality - assessment and management. Journal of Environmental Quality, 38(6), 2478-2478. [CrossRef]

Toor, G. S. \& Lusk, M. (2011). Reclaimed water use in the landscape: understanding landscape irrigation water quality tests. University of Florida, IFAS Extension, SL341, 1-9. Retrieved from https://discover. pbcgov.org/coextension/horticulture/pdf/commercial/ Understanding_reclaimed_tests.pdf (accessed 10.03.2020).

Van Loon, C. J. (1980). Analytical Atomic Absorption Spectroscopy: Selected Methods. Academic Press, ISBN:978-0-12-714050-6.

Vuralın, A. \& Müftüoğlu, N. M. (2012). Farklı dozlarda uygulanan molibdenin bakla (Vicia faba L.) bitkisinin azot içeriğine etkisi. Ege Üniversitesi Ziraat Fakültesi Dergisi, 49(1), 53-62.

Welz, B. \& Sperling, M. (1999). Atomic Absorption Spectrometry. Third Edition. WILEY-VCH Verlag GmbH, ISBN:9783527285716 [CrossRef]

Yeler, O. \& Yeler, T. S. (2019). Van ili ekolojik koşullarında kullanılması uygun bazı dış mekân süs bitkilerinin bitki gruplarına göre genel özellikleri, II. Int Sci and Acad Cong, Konya, Türkiye, 1(14), 133-145.

Yücedağ, C. \& Kaya, L. G. (2016). Hava kirleticilerin bitkilere etkileri. Mehmet Akif Ersoy Üniversitesi Fen Bilimleri Dergisi, 7(1), 67-74. [CrossRef] 